\title{
FACTORS ASSOCIATED WITH OVERWEIGHT AND OBESITY IN ADOLESCENTS IN KARTASURA, CENTRAL JAVA
}

\author{
Sayida Royatun Niswah' ${ }^{1)}$, RB Soemanto ${ }^{2}$, Bhisma Murti ${ }^{1)}$ \\ ${ }^{1)}$ Masters Program in Public Health, Sebelas Maret University \\ 2)Faculty of Social and Political Sciences, Sebelas Maret University
}

\begin{abstract}
Background: Adolescents experience rapid growth. Therefore, they are at risk to have malnutritional problems such as overweight and obesity. The Indonesian Basic Health Research in 2013 showed that the prevalence of overweight among adolescents aged 13-15 years old in Indonesia was $10.8 \%$, consisting of $8.3 \%$ overweight and $2.5 \%$ obese or very obese. The prevalence of overweight and obesity in adolescents aged 15 years and over was $18.4 \%$ in Central Java, and $10.7 \%$ in Surakarta. Overweight and obesity are important public health problems because they are known as risk factors of various chronic diseases. This study aimed to determine the factors associated with overweight and obesity in adolescents using Health Belief Model.
\end{abstract}

Subjects and Method: This was an analytic observational study with crosssectional design. The study was conducted at Islamic Boarding School (Pondok Pesantren Modern Islam) Assalaam Kartasura, Central Java, from March to May 2017. A total sampel of 120 adolesents aged 12 to 18 years old were selected for this study using fixed disease sampling, including 30 adolescents with overweight or obesity and 90 adolescents with normal weight. The exogenous variables were perceived threat, perceived benefit, perceived barrier, self efficacy, and maternal education. The endogenous variables were physical activity, dietary pattern, and overweight or obesity. Data on dietary pattern were collected by dietary questionnnaire. The other data were collected using a set of questionnaire. Path analysis was used to analyze the association between variables involving mediating variables.

Results: Overweight or obesity was directly and negatively associated with perceived threat $(b=-0.14, \mathrm{SE}=0.04, \mathrm{p}<0.001)$, perceived benefit $(\mathrm{b}=-0.10, \mathrm{SE}=$ $0.02, \mathrm{p}<0.001)$, physical activity $(\mathrm{b}=-0.24, \mathrm{SE}=0.10, \mathrm{p}=0.016)$, and dietary pattern $(b=-0.33, \mathrm{SE}=0.08, \mathrm{p}<0.001)$. Overweight or obesity was directly and positively associated with perceived barrier $(b=0.13, \mathrm{SE}=0.07, \mathrm{p}=0.051)$. Dietary pattern was affected by perceived barrier $(b=-0.22 ; \mathrm{SE}=0.007 ; \mathrm{p}=$ 0.002), perceived benefit $(b=0.10 ; S E=0.002 ; p<0.001)$, perceived threat $(b=$ 0.09; $\mathrm{SE}=0.04 ; \mathrm{p}=0.023)$, self effication $(\mathrm{b}=0.22 ; \mathrm{SE}=0.09 ; \mathrm{p}=0.015)$, and maternal education $(b=1.05 ; \mathrm{SE}=0.41 ; \mathrm{p}=0.010)$. Physical activity was affected by perceived benefit $(b=0.05 ; \mathrm{SE}=0.001 ; \mathrm{p}=0.002)$, perceived barrier $(b=-0.16$; $\mathrm{SE}=0.05 ; \mathrm{p}=0.002)$, perceived threat $(\mathrm{b}=0.14 ; \mathrm{SE}=0.03 ; \mathrm{p}<0.001)$, self efficacy $(\mathrm{b}=0.24 ; \mathrm{SE}=0.06 ; \mathrm{p}<0.001)$, and maternal education $(\mathrm{b}=0.86 ; \mathrm{SE}=0.30 ; \mathrm{p}=$ 0.005).

Conclusion: Overweight or obesity is negatively associated with perceived threat, perceived benefit, physical activity, and dietary pattern. Overweight or obesity is positively associated with perceived barrier. Health Belief Model can be used to explain factors associated with overweight or obesity.

Keywords: overweight, obesity, Health Belief Model

Correspondence: Sayida Royatun Niswah. Masters Program in Public Health, Sebelas Maret University, Jl. Ir. Sutami 36 A, Surakarta 57126, Central Java. Email: cestrowsha@gmail.com. Mobile: +6285700189910. 